\title{
STUDIES ON PHOSPHODEOXYRIBOMUTASE
}

\author{
CHARLES G. SMITH AND I. A. BERNSTEIN \\ Research Laboratories, The Upjohn Company, Kalamazoo, Mich. (U.S.A.) and \\ Department of Dermatology and the Institute of Industrial Health, \\ University of Michigan, Ann Arbor, Mich. (U.S.A.) \\ (Received February 27th, 196I)
}

\section{SUMMARY}

A phosphodeoxyribomutase has been demonstrated in cell-free extracts of Sarcina lutea. The enzyme could be heated to $55^{\circ}$ for at least $2 \mathrm{~h}$ and still retain activity. It had a $\mathrm{pH}$ optimum around 7.2 , and the most highly purified preparation showed a specific activity of approx. $60 \mu$ moles of deoxyribose I-phosphate converted to deoxyribose 5 -phosphate/mg protein/h. The enzyme was constitutive in the above organism, but could not be demonstrated conclusively in extracts of I4 other microorganisms tested.

The enzymic conversion of deoxyribose I-phosphate to deoxyribose 5-phosphate was established by isolation and enzymic characterization of the product. The enzyme was also able to convert deoxyribose 5-phosphate to pyrimidine-bound deoxyribose, presumably through deoxyribose I-phosphate. Chromatographic and radiographic studies indicated that, at equilibrium, the reaction contains approx. $95 \%$ deoxyribose 5-phosphate and 5\% deoxyribose I-phosphate.

The mutase was shown to be inhibited by inorganic phosphate at low concentrations, and by deoxyribose I-phosphate, deoxyribose 5-phosphate, potassium sulfate and fructose 6-phosphate. The enzyme appeared to be stimulated by fructose I,6diphosphate. The inhibitions by inorganic phosphate and sulfate confirm previous reports in the literature.

Acetaldehyde and an aqueous extract of Whatman No. I filter paper were shown to interfere with the cysteine-sulfuric acid reaction with deoxyribose.

\section{INTRODUCTION}

The metabolic degradation of nucleoside-DR in animal and microbial cells has been shown to proceed via DR I-P1, 2 to DR $5-\mathrm{P}^{3-5}$ which is finally split to glyceraldehyde phosphate and acetaldehyde ${ }^{3,4,6}$. The conversion of $\mathrm{DR} 5-\mathrm{P}$ to nucleoside-bound $\mathrm{DR}$, presumably via DR I-P, has also been reported". The isolation of DR I,5-diP from ling-cod muscle ${ }^{8}$ further suggests the presence of a phosphodeoxyribomutase, requiring the diphosphate as co-enzyme. Although it appears that the deoxyribosyl moiety may arise by reduction of the ribosyl moiety ${ }^{9-14}$, probably at the nucleotide level,

Abbreviations: deoxyribose, DR; deoxyribose I-phosphate, DR I-P; deoxyribose 5-phosphate, DR 5-P; deoxyribose I,5-diphosphate, DR 1,5-diP; thymine, T. 
the degradation of nucleoside-bound deoxyribose would seem to occur via the intermediates noted above ${ }^{6,9}$.

The work reported herein was undertaken in an effort to produce deoxyribosides in quantity from the inexpensive starting materials acetaldehyde and hexosediphosphate. The interconversion of DR I-P and DR 5-P, which could be demonstrated in the presence of a cell free extract of Sarcina lutea PCI-IooI (UC-I28) is reported in this publication.

\section{MATERIALS AND METHODS}

The initial test for the detection of mutase activity was carried out in a reaction mixture containing Io $\mu$ moles $/ \mathrm{ml}$ each of deoxyadenosine and $\mathrm{Pi}$ in $0.05 M$ maleate buffer at $\mathrm{pH} 6.5$, plus approx. $3 \mathrm{mg} / \mathrm{ml}$ of protein extracted from Escherichia coli $\mathrm{Wc}-$. The E. coli preparation was obtained from cells which had previously been grown aerobically at $32^{\circ}$ in a medium containing glucose, Io $\mathrm{g} / \mathrm{l}$ of distilled water; acetic acid, $5 \mathrm{~g} / \mathrm{l}$; yeast extract, $3 \mathrm{~g} / \mathrm{l}$; beef extract, $3 \mathrm{~g} / \mathrm{l}$; potassium phosphate, $2 \mathrm{~g} / \mathrm{l}$; magnesium sulfate, $0.2 \mathrm{~g} / \mathrm{l}$; manganese, iron and zinc, $0.00 \mathrm{I} \mathrm{g} / \mathrm{l}$ each; and cytosine, $0.5 \mathrm{~g} / 1$. The presterilization $\mathrm{pH}$ was adjusted to 8 with $\mathrm{NH}_{3}$. The cells, obtained in a concentration of 8 to Io $\mathrm{g} / \mathrm{l}$ (dry wt.), were harvested after approx. I6 $\mathrm{h}$ growth, washed with one volume of distilled water and ground for several minutes in a mortar with an equal weight of powdered Pyrex glass (300 mesh). The ground residue was extracted with 5-Io volumes of distilled water and this suspension was centrifuged at $0^{\circ}$ for $30 \mathrm{~min}$ at $30000 \times g$. The supernatant fraction, containing approx. Io $\mathrm{mg} / \mathrm{ml}$ of protein, was diluted four fold for the mutase assay. In the above reaction mixture, deoxyadenosine was added as a source of DR I-P which was not metabolized further unless S. lutea extract was also added. Total DR (O.I to 0.8 $\mu$ mole $/ 6 \mathrm{ml}$ reaction) was determined by the method of DischE ${ }^{15}$ using deoxyadenosine as standard and measuring $A_{595}-A_{650}$. Mutase activity was indicated by a disappearance of the DR moiety. Excess deoxyribose phosphate aldolase? for the degradation of DR $5-\mathrm{P}$ was provided in the E. coli extract. Aqueous extracts of the following organisms, prepared by the procedure described above, showed no mutase activity in the deoxyadenosine-E. coli system: Salmonella typhi, Salmonella pullorum,

TABLE I

\begin{tabular}{|c|c|c|c|}
\hline \multirow{2}{*}{$\begin{array}{c}\text { Thymidine } \\
\text { concentration } \\
(\mu \mathrm{g} / \mathrm{ml})\end{array}$} & \multirow{2}{*}{$\begin{array}{l}\text { Acetaldehyde } \\
\text { concentraticn } \\
\quad(\mu \mathrm{g} / m l)\end{array}$} & \multicolumn{2}{|c|}{$A_{490}{ }^{\star}$} \\
\hline & & Unheated & Healed $d^{\star \star}$ \\
\hline I 4.5 & $\mathrm{O}$ & 0.54 & \\
\hline I 4.5 & 0.18 & 0.44 & \\
\hline 14.5 & I. 8 & 0.17 & \\
\hline I $4 \cdot 5$ & I 8 & 0.11 & \\
\hline 0 & I 8 & 0.0 & \\
\hline I 4.5 & o & 0.54 & 0.62 \\
\hline$I_{4} \cdot 5$ & 3.6 & 0.15 & 0.61 \\
\hline 7.2 & 0 & 0.20 & 0.23 \\
\hline 7.2 & 3.6 & 0.06 & 0.23 \\
\hline
\end{tabular}

\footnotetext{
* Determined with a Beckman Spectrophotometer, Model B. Dose-response curves gave straight line functions which did not pass through the origin.

$\star$ Steam bath for ro min before the addition of cysteine or sulfuric acid.
} 
Proteus vulgaris, Mycobacterium avium, Candida albicans, Saccharomyces pastorianus, Saccharomyces cerevisiae, Klebsiella pneumoniae, Pseudomonas aeruginosa, Salmonella paratyphi, Serratia marcescens, Staphylococcus albus and Staphylococcus aureus. Protein content of the above extracts varied from 4 to $19 \mathrm{mg} / \mathrm{ml}$.

When an extract of $S$. lutea, to give $1.5 \mathrm{mg}$ of protein $/ \mathrm{ml}$, was added to the mixture of deoxyadenosine (or thymidine), $E$. coli extract and buffer, DR disappeared after 30 min incubation at $37^{\circ}$.

When thymidine was used as substrate for the mutase studies, DR was determined by the cysteine-sulfuric acid method of STUMPF ${ }^{16}$. During the course of these investigations, it was observed that acetaldehyde, formed from DR 5-P by deoxyribose aldolase $e^{5,7}$, interfered with the cysteine-sulfuric acid reaction for DR as illustrated in Table I. These data show that acetaldehyde could be removed from the reaction mixture before the cysteine and sulfuric acid were added by steaming for Io min, and this procedure was adopted for all subsequent determinations. Acetaldehyde per se did not react with the cysteine-sulfuric acid reagent.

An aqueous extract of Whatman No. I filter paper was also found to interfere with the cysteine-sulfuric acid reaction with DR. When the paper was extracted with hot water and the concentrated extract added to deoxyadenosine standards, development of color with cysteine-sulfuric acid resulted in (a) an approximate five fold decrease in absorbancy/unit weight of DR and (b) a change in the spectral curve which was found to contain a shoulder at $475 \mathrm{~m} \mu$ in addition to the expected peak at 490-495 $\mathrm{m} \mu$. These changes were also evident with DR samples which were chromatogrammed on Whatman No. I paper and isolated by extraction with hot water.

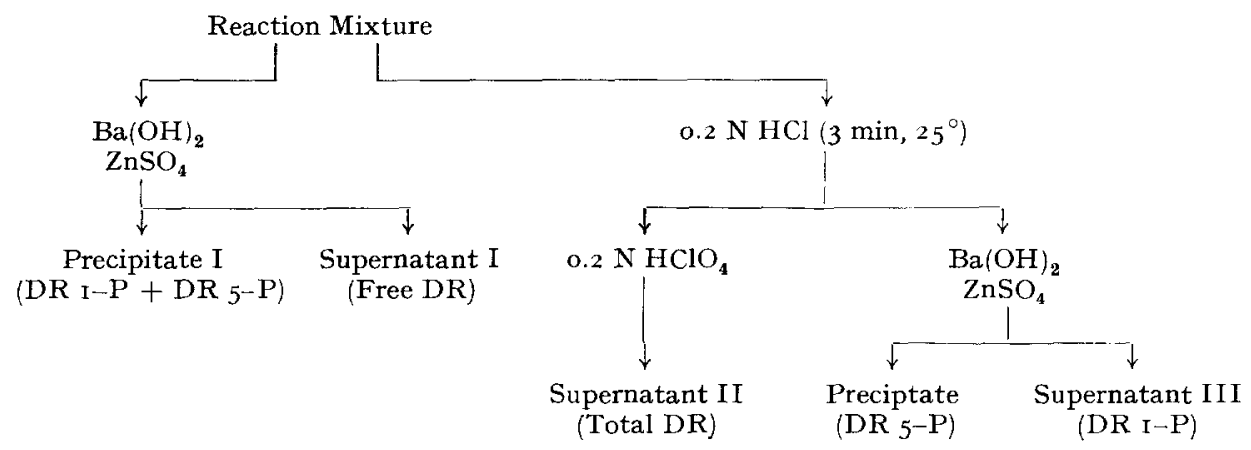

Fig. I. Precipitation scheme for analysis of DR I-P conversion.

Crystalline DR I-P was prepared as the dicyclohexylamine salt according to the method of FrIEDKIn ${ }^{17}$ as modified by McDonald AND FLETCHER ${ }^{18}$. DR 5-P was prepared by the method of PRICER ${ }^{21}$ and was characterized as described by RACKER ${ }^{22}$. The conversion of DR I-P to DR 5-P was measured quantitatively using the precipitation scheme shown in Fig. I. The salient features of this scheme are the following. (a) The initial precipitation with barium hydroxide (I) measures any reaction which might liberate free DR (supernatant) from DR I-P or DR 5-P (precipitate). (b) Following incubation for $3 \mathrm{~min}$ at $25^{\circ}$ in $0.2 \mathrm{~N} \mathrm{HCl}, \mathrm{DR} \mathrm{I}-\mathrm{P}$ is cleaved rapidly to free DR whereas DR 5-P is not. In fraction II, total DR in the reaction mixture is measured and any disappearance of the sugar moiety would be observed here (e.g., pyrimidine 
binding or aldolase activity). In fraction III, free DR (from DR I-P) is present in the supernatant fluid whereas $\mathrm{DR} 5-\mathrm{P}$ is precipitated as the barium salt.

When DR I-P is converted to DR 5-P, there is no change in the barium soluble fraction (I) or the total DR moiety (II), but there is a decrease in the free DR after acid treatment (III), as shown in Fig. 2.

$S$. lutea extracts were prepared as described above for $E$. coli or in an Eppenbach colloid mill through the courtesy of Dr. J. GARver ${ }^{19}$. S. lutea was grown in a medium containing glucose, Io $\mathrm{g} / \mathrm{l}$; acetic acid, $5 \mathrm{~g} / \mathrm{l}$; yeast extract, $3 \mathrm{~g} / \mathrm{l}$; beef extract, $3 \mathrm{~g} / \mathrm{l}$; $\mathrm{KH}_{2} \mathrm{PO}_{4}, 2 \mathrm{~g} / \mathrm{l} ; \mathrm{MgSO}_{4}, 0.2 \mathrm{~g} / \mathrm{l} ; \mathrm{Mn}, \mathrm{Fe}$ and $\mathrm{Zn}$, o.oor $\mathrm{g} / 1 ; \mathrm{NH}_{3}$ to $\mathrm{pH} 8$, on a Gump rotary shaker at $250 \mathrm{rev} . / \mathrm{min}$ and $32^{\circ}$ in an indented shake flask ${ }^{\mathbf{2 0}}$. Under these conditions of growth, approx. $8 \mathrm{~g} / \mathrm{l}$ of dry cell weight were obtained after $\mathrm{I} 8-20 \mathrm{~h}$ incubation. Radioactivity was measured with a Geiger-Müller counter using a Micromil gas flow window.

\section{EXPERIMENTAL}

\section{Purification of mutase}

The original S. lutea extract, prepared as described above, contained pyrimidine phosphorylase and deoxyribose-aldolase activities which interfered with the determinations of DR I-P and DR 5-P. When the crude enzyme preparation was heated at $55^{\circ}$ for $15,30,60$ and $120 \mathrm{~min}$, and mutase activity determined in the presence of thymidine, $P_{1}$ and $E$. coli extract, the specific mutase activity was increased approximately three fold (Table II) while phosphorylase and aldolase activities were completely destroyed. Following the heat treatment, the crude preparation was adjusted to $\mathrm{pH} 4.5$ with acetic acid at $0^{\circ}$, the precipitate removed by centrifugation and the supernatant fluid readjusted to $\mathrm{pH} 6.5$ to 7 . This procedure also increased the specific activity as shown in Table II. Approx. $5^{\circ} \mathrm{ml}$ of enzyme preparation was next dialyzed for $48 \mathrm{~h}$ against 51 of deionized water which resulted in an over-all purification (units/mg protein) of approximately ten fold. More important perhaps than the absolute increase in specific activity is the fact that the heat treatment rendered this preparation essentially free of contaminating enzyme activities such as aldolase and nucleoside phosphorylase and allowed the direct measurement of the conversion of DR I-P to DR 5-P.

TABLE II

\begin{tabular}{lc}
\multicolumn{1}{c}{ PREPARATION OF MUTASE FROM S. lutea } \\
\hline \multicolumn{1}{c}{ Treatment $^{\star}$} & $\begin{array}{c}\text { Specific activity } \\
\text { emoles converted/mg } \\
\text { protein/ } h^{\star}\end{array}$ \\
\hline I. None & 0.8 \\
2. $55^{\circ}$ for I 5-I 20 min ${ }^{\star \star \star}$ \\
3. Precipitate with acetic acid at $\mathrm{pH} 4.5$ \\
$\begin{array}{l}\text { (a) Supernatant fluid } \\
\text { (b) Precipitate }\end{array}$ \\
$\begin{array}{l}\text { 4. Supernatant fluid dialyzed } 48 \mathrm{~h} \\
\text { against water }\end{array}$ \\
\hline
\end{tabular}

\footnotetext{
* Details of purification treatments given in text.

* Determined as disappearance of DR from thymidine in the presence of phosphate and extract of $E$. coli, as described in text.

$\star \star \star ~ 100^{\circ}$ for 3 min completely inactivated the preparation.
} 


\section{Conversion of $D R{ }_{I-P}$ to $D R R_{5}-P$}

The conversion of DR I-P (I2 $\mu$ moles/ml) to DR $5-\mathrm{P}$, using the heat treated dialyzed enzyme preparation (at $3 \mathrm{mg} / \mathrm{ml}$ total solids; I $\mathrm{mg}$ protein $/ \mathrm{ml}$ ) shown in Table II, was carried out in $0.05 M$ maleate buffer at $\mathrm{pH} 7.5$ and $37^{\circ}$. Total $\mathrm{DR}$ and DR I-P were determined by the DISche reaction (see Fig. I and METHODS) and the results are presented in Fig. 2. Subsequent investigations showed that approximately $90 \%$ of the DR I-P was converted to acid stable, barium-insoluble DR (DR-5-P) after $2 \mathrm{~h}$ incubation.

Aliquots removed at $\mathrm{o}$ and $\mathrm{I00} \mathrm{min}$ were chromatogrammed in a solvent system consisting of I-butanol-glacial acetic acid-water (2:I:I, v/v). After development overnight, the papers were sprayed with cysteine-sulfuric acid ${ }^{23}$ and thiobarbituric acid reagents ${ }^{24}$ to visualize $D R$. The o-min sample contained only DR I-P, which migrated as the free sugar in the acid system employed. After 60 and $100 \mathrm{~min}$ of enzyme treatment, however, the DR spot $\left(R_{F}\right.$ 0.65) decreased sharply in intensity and a spot which migrated with DR $5-\mathrm{P}\left(R_{F} 0.35\right)$ appeared and increased in intensity. When these spots were eluted from the papergram and reacted with cysteine-sulfuric acid $^{16}$ and the Dische reagent ${ }^{15}$, both showed spectra which could not be differentiated from known DR.

\section{Isolation of $D R$ 5-P}

A large scale experiment was carried out to isolate and identify the product formed from DR I-P by the $S$. lutea preparation. Twenty millilitres of reaction mixture (as described above), containing $44^{\circ} \mu$ moles of DR 5 -P by assay, were steamed for 3-4 min, and freeze-dried. The dried residue was taken up in ro $\mathrm{ml}$ of cold $\mathrm{H}_{2} \mathrm{O}$ and the protein precipitated by the addition of $0.5 \mathrm{ml}$ of cold $70 \% \mathrm{HClO}_{4}$. The precipitated protein was removed by centrifugation. The supernatant fluid was adjusted to $\mathrm{pH} 7.2$ with $\mathrm{KOH}$ and the $\mathrm{KClO}_{4}$ which precipitated was removed by filtration. A portion of this filtrate, containing $5^{\circ} \mu$ moles of deoxyribose, was chromatographed at $0^{\circ}$ on a column of Dowex-I acetate ( $I .2 \mathrm{~cm}$ in diameter by $I 5 \mathrm{~cm}$ in length) using the gradient solvent system (ammonium acetate) of PRICER ${ }^{21}$. The material eluted between Ioo and 2 IO $\mathrm{ml}$ gave a positive reaction with diphenylamine as did an authentic sample of DR $5-\mathrm{P}$ chromatographed in the same way. $70 \%$ of the starting material was recovered in these fractions in the case of the experimental and $88 \%$ with the authentic sample. Precipitation as the barium salt ${ }^{21}$ by the addition of $\mathrm{BaBr}_{2}$ and four volumes of acetone at - $-\mathrm{ro}^{\circ}$ yielded a water soluble product in $63 \%$ yield which assayed $92 \%$ pure by diphenylamine (the authentic sample was $95 \%$ pure by the same criterion). An aliquot was converted to a mixture of acetaldehyde and 3 -phosphoglyceraldehyde with purified deoxyribose phosphate aldolase ${ }^{21}$, and the products assayed enzymically ${ }^{22}$ using alcohol dehydrogenase and diphosphopyridine nucleotide for acetaldehyde and triose phosphate isomerase, $\alpha$-glycerophosphate dehydrogenase and diphosphopyridine nucleotide for glyceraldehyde phosphate. 96 and $94 \%$, respectively, of the theoretical amounts of the products were obtained.

\section{Effect of $p H$ on mutase activity}

The $\mathrm{pH}$ optimum of the mutase reaction was determined in maleate buffer using DR I-P as described above and the results are shown in Table III. A pH optimum of approx. 7.2 was confirmed using buffers other than maleate. 


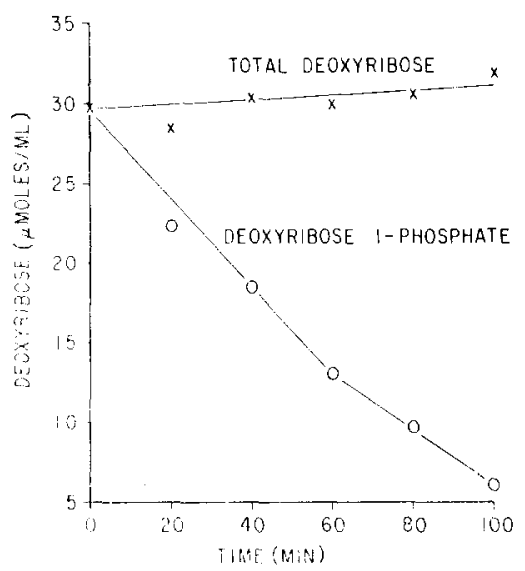

Fig. 2. Conversion of DR I-P to DR $5-P$.

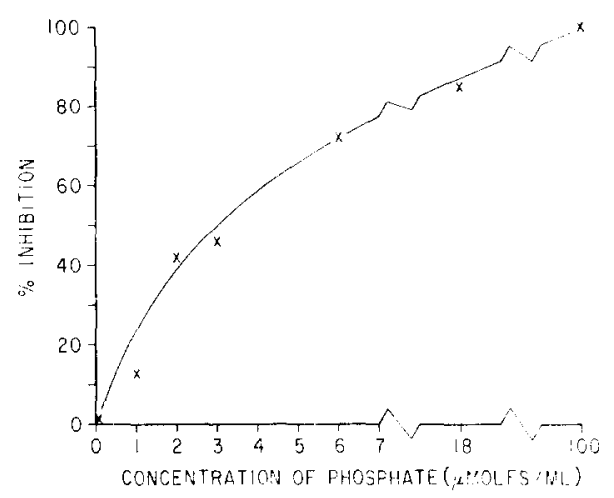

Fig. 3. Effect of phosphate on mutase reaction.

TABLE III

EFFECT ON PH ON MUTASE ACTIVITY

Reaction mixture contained I $2 \mu$ moles DR I-P $+1 \mathrm{mg} S$. lutea protein in I $\mathrm{ml} 0.05 M$ maleate buffer. Temperature of reaction was $37^{\circ}$. Conversion was determined as shown in Fig. I.

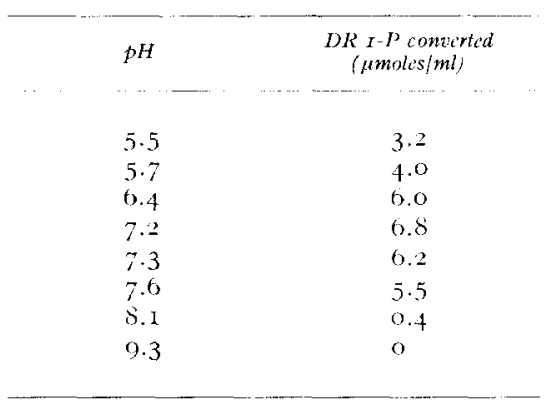

TABLE IV

EFFECT OF DEOXYRIBOSE PHOSPHATES ON MUTASE ACTIVITY

\begin{tabular}{|c|c|c|}
\hline $\begin{array}{c}D R \quad \text { I-P concentratic } n^{*} \\
(\text { (umoles } / \text { ml })\end{array}$ & $\begin{array}{c}\text { DR } 5 . P \text { concentration } \\
(\mu \text { moles } / \text { ml })\end{array}$ & $\begin{array}{l}\text { Relative rate } \\
\text { of reaction }\end{array}$ \\
\hline 6 & 0 & I.O \\
\hline 8.6 & 0 & 0.67 \\
\hline $\mathrm{I} \geq .2$ & o & 0.5 \\
\hline 27 & 0 & 0.35 \\
\hline 55 & 0 & 0 \\
\hline 12.5 & $o$ & 1.0 \\
\hline 12.5 & IO & 0.5 .5 \\
\hline
\end{tabular}

* At beginning of reaction, added as dicyclohexylamine salt.

* Measured at I 5-20 min with I $2 \mu$ moles $/ \mathrm{ml}$ of DR I-P as substrate in I $\mathrm{ml}$ of $0.05 M$ maleate buffer $\mathrm{pH} 7.5$, as shown in Fig. I. S. lutea mutase preparation added at a final concentration of $1 \mathrm{mg}$ of protein $/ \mathrm{ml}$. Temperature of incubation $37^{\circ}$. Maximum specific activity observed was $60 \mu$ moles DR $\mathrm{I}-\mathrm{P}$ converted $/ \mathrm{mg}$ protein $/ \mathrm{h}$. Cyclohexylamine $\mathrm{HCl}$ was not inhibitory at a concentration of $5^{\circ} \mu$ moles $/ \mathrm{ml}$. 
Effect of substrate and product concentration on reaction rate

Both DR I-P and DR 5-P were found to inhibit the rate of mutase reaction as shown in Table IV. The inhibition by both substrate and product made the determination of the Michaelis constant essentially meaningless, since the rate was changing throughout the course of the reaction as a function of the relative concentrations of DR I-P and DR 5-P.

\section{Effect of phosphate and sulfate on the rate of reaction}

HoFFMAN AND LAMPEN ${ }^{3}$ described the inhibition of the conversion of DR I-P to DR 5-P in E. coli by $\mathrm{P}_{1}$ and sulfate. The effect of $\mathrm{P}_{1}$ on the conversion of DR I-P by the $S$. lutea mutase was determined by incubating $\mathrm{I} \mathrm{ml}$ of reaction mixture containing I2 $\mu$ moles $/ \mathrm{ml}$ of DR I-P, varying concentrations of $\mathrm{P}_{1}$, and $3 \mathrm{mg} / \mathrm{ml}$ of enzyme preparation in $0.05 M$ maleate buffer at $\mathrm{pH} 7.5$ at $37^{\circ}$ and measuring residual DR I-P as shown in Fig. I. The results of this study are shown in Fig. 3. The mutase reaction was inhibited $50 \%$ in the presence of $3 \mu$ moles $/ \mathrm{ml}$ of $P_{1}$.

The inhibition by phosphate did not appear to be competitive since it varied only from $48 \%$ to $55 \%$ when the $\mathrm{DR} \mathrm{I}-\mathrm{P}$ concentration was varied from $\mathrm{I} 2$ to $6 \mu \mathrm{moles} / \mathrm{ml}$ in the presence and absence of $4 \mu \mathrm{moles} / \mathrm{ml}$ of $P_{i}$. The mutase reaction did not appear to be inhibited by $P_{1}$ when the substrate was a purine deoxyriboside or thymidine, but this observation was complicated by the fact that $P_{i}$ was a required intermediate in this reaction.

Sulfate was also inhibitory to the mutase as previously described ${ }^{3}$. When potassium sulfate was added at a concentration of $5^{\circ} \mu$ moles $/ \mathrm{ml}$, the reaction was inhibited approx. $30 \%$ (DR I-P at I $2 \mu$ moles $/ \mathrm{ml})$.

\section{Effect of other sugar phosphates on the mutase reaction}

Since DR I-P, DR 5-P and $P_{1}$ all inhibited the conversion of DR I-P to DR 5-P, the effects of other sugar phosphates were also investigated. Barium ion was removed where required by precipitation with oxalate, which itself was shown not to interfere with the mutase reaction. Results of these studies are presented in Table V. These data show marked (albeit opposite) effects on the mutase reaction only by fructose 6-phosphate and fructose 1,6-diphosphate.

TABLE $\mathrm{V}$

EFFECT OF VARIOUS SUGAR PHOSPHATES ON MUTASE REACTION

Reaction mixture contained DR I-P, I $2.5 \mu$ moles $/ \mathrm{ml}$ in maleate buffer, as described in Table IV Sugars, obtained from Nutritional Biochemical Corporation were added at zero time.

\begin{tabular}{|c|c|c|}
\hline $\begin{array}{c}\text { Sugar added } \\
\text { (at so } \mu \text { moles }(m i)\end{array}$ & $\begin{array}{l}\text { Per cent } \\
\text { inhibition }\end{array}$ & $\begin{array}{c}\text { Percent } \\
\text { stimulaticn }\end{array}$ \\
\hline $\begin{array}{l}\text { Ribose 5-phosphate } \\
\text { Galactose 6-phosphate } \\
\text { Glucose 6-phosphate } \\
\text { 3-Phosphoglyceric acid } \\
\text { Fructose 6-phosphate } \\
\text { Fructose I,6-diphosphate } \\
\text { Glucose I-phosphate }\end{array}$ & $\begin{array}{r}9 \\
\text { I } 5 \\
9 \\
44,40 \\
0\end{array}$ & $\begin{array}{c}4 \\
4^{8,25}\end{array}$ \\
\hline
\end{tabular}




\section{Effect of magnesium and cysteine}

Magnesium and cysteine are required for optimum activity of phosphoglucomutase ${ }^{25,26}$. Cysteine, at $5 \mu \mathrm{moles} / \mathrm{ml}$, was found to accelerate the conversion of DR I to DR 5-P only slightly, whereas magnesium ion had no effect on the reaction.

\section{Reversibility of the mutase reaction}

RACKER described the synthesis of hypoxanthine deoxyriboside from DR 5 -P and hypoxanthine in the presence of $E$. coli extract? When DR $5-\mathrm{P}(8 \mu \mathrm{moles} / \mathrm{ml})$ and thymine $(5 \mu \mathrm{moles} / \mathrm{ml})$ were incubated at $37^{\circ}$ with the $S$. lutea mutase $(3 \mathrm{mg} / \mathrm{ml})$ in $0.05 M$ maleate buffer at $\mathrm{pH} 7.5$ in the presence of $E$. coli thymidine phosphorylase (specific activity of $430 \mu$ moles thymine liberated/mg protein/h), I-I.75 $\mu$ moles $/ \mathrm{ml}$ of thymidine were formed. This conversion is shown chromatographically in Fig. 4, which establishes the reversibility of the mutase.

When DR 5-P was incubated with the mutase in the absence of an acceptor for DR I-P, approx. $0.5 \mu \mathrm{mole} / \mathrm{ml}$ of DR I-P were formed in $20 \mathrm{~min}$ from $8 \mu \mathrm{moles} / \mathrm{ml}$ of DR 5-P. The conversion was established by (a) the production of acid labile DR-P and (b) paper chromatographic analysis using the thiobarbituric acid spray reagent ${ }^{\mathbf{2 4}}$. Since approx. $0.5 \mu$ mole of DR I-P were present per millilitre when the conversion of DR I-P ( $2 \mu$ moles $/ \mathrm{ml}$ ) to DR $5-\mathrm{P}$ was measured, these data indicate that, at equilibrium, approx. $95 \%$ of the sugar is present as the 5-phosphate.

${ }^{\left[{ }^{14} \mathrm{C}\right] D R} 5-\mathrm{P}$, prepared from fructose $\left[1,6-{ }^{14} \mathrm{C}\right]$ diphosphate by the method of PRICER $^{21}$ was submitted to the $S$. lutea preparation at $3.3 \mu$ mole of DR $5-\mathrm{P} / \mathrm{ml}$ in $0.5 M$ Tris buffer at $\mathrm{pH} 7.5$. After $90 \mathrm{~min}, 0.5 \mathrm{ml}$ of the incubation mixture was exposed to $0.2 \mathrm{~N} \mathrm{HCl}$ at room temperature for $20 \mathrm{~min}$ to hydrolyze any DR I-P

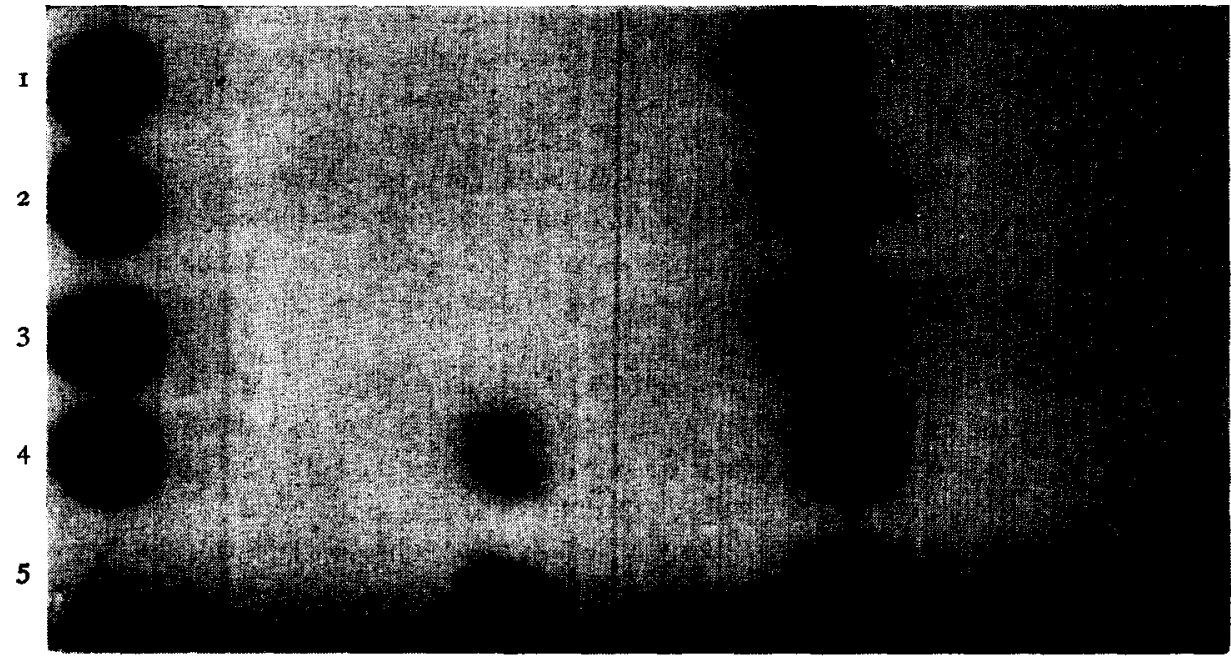

Fig. 4. Papergram demonstration of thymine synthesis. I, Zero-min sample, DR $5-\mathrm{P}$ omitted ${ }^{\star}$; 2, 40-min sample, DR 5-P omitted; 3, Zero-min sample, DR 5-P present; 4, 40-min sample, DR 5-P present; 5 , thymidine $(5 \circ \mu \mathrm{g})+$ thymine $(25 \mu \mathrm{g})$ standard.

* Reaction mixture contained thymine $(5 \mu M / \mathrm{ml}), S$. lutea preparation $(3 \mathrm{mg} / \mathrm{ml})$ and thymidine phosphorylase (I $\mathrm{mg} / \mathrm{ml}$ ) in maleate buffer. DR 5 -P added as noted above. Papergram was developed for $16 \mathrm{~h}$ by the descending technique in ethyl acetate saturated with $0.05 M$ phosphate buffer at $\mathrm{pH} 6$ after equilibration for $3 \mathrm{~h}$. 
formed and chromatogrammed on a column of Dowex-I acetate as previously described. Any free deoxyribose formed by hydrolysis of DR I-P in $0.2 N \mathrm{HCl}$ would not adsorb on the resin and would be seen as ${ }^{14} \mathrm{C}$ in the effluent. The starting ${ }^{\left[{ }^{14} \mathrm{C}\right] \mathrm{DR}}$ 5 -P had a specific activity of 12300 counts $/ \mathrm{min} / \mu$ mole. The ${ }^{14} \mathrm{C}$ which did not adsorb on the column after $90 \mathrm{~min}$ of incubation corresponded to the conversion of a minimum of $0 . \mathrm{I} \mu \mathrm{mole} / \mathrm{ml}$ of $\mathrm{DR} 5-\mathrm{P}$ to $\mathrm{DR}$ I-P respectively. Further purification of this enzyme will be required before an accurate determination of the equilibrium point is possible.

\section{DISCUSSION}

The above data confirm the existence of a phosphodeoxyribomutase which catalyzes the interconversion of DR $\mathrm{x}-\mathrm{P}$ and DR $5-\mathrm{P}$. Deoxyribosides can be converted to DR I-P via the action of purine and pyrimidine phosphorylases ${ }^{1,2}$. The DR I-P can then be converted to $\mathrm{DR}{ }_{5} \mathrm{P}$ in the presence of the mutase ${ }^{3,4}$ and $\mathrm{DR} 5 \mathrm{P}$ finally cleaved by DR-aldolase to triosephosphate and acetaldehyde?

The synthesis of deoxyribonucleotides appears to proceed in bacteria and animal cells by the direct reduction of ribonucleotides ${ }^{13,14}$. The existence of a mutase which can convert DR 5-P to DR I-P points to this pathway as a possible alternate for deoxynucleoside synthesis. RACKER ${ }^{7}$ was able to demonstrate the synthesis of deoxyribosides from $\mathrm{DR} 5-\mathrm{P}$ and hypoxanthine and the data presented above illustrate the synthesis of thymidine from thymine and DR $5-\mathrm{P}$. In the presence of small amounts of phosphate (5-Io $\mu$ moles $/ \mathrm{ml}$ ), however, no conversion of DR $5-\mathrm{P}$ to DR I-P could be demonstrated in the $S$. lutea system. It was further noted in the above studies that DR $x-P, D R 5-P$ and fructose 6-phosphate all inhibited the mutase reaction. With these possibilities for physiologic control of phosphodeoxyribomutase, one cannot predict or estimate the extent to which this enzyme may be employed in the synthesis of deoxyribosides in intact cells. Studies with radioactive compounds have indicated that the mutase pathway from DR ${ }_{-}-\mathrm{P}$ is not important in the synthesis of deoxyribosides in $E$. coli $i^{9}$. Using $E$. coli ${ }_{15}$, whole cells of which degrade thymidine to thymine, ethanol, $\mathrm{CO}_{2}$ and acetate, extremely low mutase activity was observed in a cell-free preparation tested as described above. The mutase was very difficult to demonstrate in extracts of $E$. coli even after extensive dialysis to remove $P_{1}$, and further work is needed to explain the difference between this organism and S. lutea.

The interference of acetaldehyde and an aqueous extract of Whatman No. I filter paper with the cysteine-sulfuric acid reaction for deoxyribose should be noted. When this reagent is used to measure deoxyribose under conditions where acetaldehyde is being produced, the apparent amount of sugar present will decrease with increasing aldehyde concentration. Likewise, when paper chromatograms are sprayed with the cysteine-sulfuric acid reagent, the intensity of the reaction is much reduced with Whatman No. I paper. Extracts of this paper added to known deoxyribose compounds also show a much reduced intensity of reaction with the cysteine-sulfuric acid reagent and a change in the spectral curve for DR. The effects of other papers were not investigated.

No absolute requirement could be shown with the $S$. lutea mutase for DR I,5diphosphate, magnesium or cysteine, although fructose I,6-diphosphate did stimulate the reaction and DR 1,5-diphosphate was not tested per se. The only attempt to 
remove such co-factors was a 48 -h dialysis against de-ionized water and it is entirely possible that the necessary co-factors were bound tightly to the enzyme and were not removed under these conditions.

\section{NOTE ADDED IN PROOF}

Most recent investigations indicate that, when all of the fructose-diphosphate is degraded enzymically or chemically, stimulatory activity is still present which appears to be due to glucose-I,6-phosphate.

(Received June 24th, I96I)

\section{ACKNOWLEDGEMENTS}

The authors acknowledge the competent technical assistance of Miss D. SwEET, Mr. W. L. Lummis, Mr. D. R. Horsfall and Mr. R. Welke. Purified thymidine phosphorylase was provided by Dr. J. E. Grady.

This work was supported in part by Contract SA-43-ph-r933, Cancer Chemotherapy National Service Center, National Cancer Institute, National Institutes of Health, Washington, D.C.

\section{REFERENCES}

1 M. Friedkin and H. M. Kalckar, $J$. Biol. Chem., i 84 (1950) 437.

2 L. A. Manson and J. O. Lampen, $J$. Biol. Chem., I93 (I95 I) 539.

3 C. E. Hoffman and J. O. Lampen, J. Biol. Chem., I98 (I952) 885.

4 C. E. Hoffman and J. O. Lampen, Federation Proc., io (195 I) I 98.

5 L. A. Manson and J. O. Lampen, J. Biol. Chem., Igi (I95 I) 95.

6 I. A. Bernstein, D. Fossitt and D. Sweet, J. Biol. Chem., 233 (I958) 1199.

7 E. RaCker, J. Biol. Chem., I96 (I952) 347 .

${ }^{8}$ H. L. A. TARR, Chem. and Ind., (1957) 562.

9 M. C. Lanning and S. S. Cohen, J. Biol. Chem., 216 (1955) I I94.

10 I. A. Bernstein and D. Sweet, $J$. Biol. Chem., 233 (1958) I I94.

11 M. R. Loeb and S. S. Cohen, J. Biol. Chem., 234 (1959) 360.

12 F. K. Bagatell, E. M. Wright and H. Z. Sable, J. Biol. Chem., 234 (1959) I369.

13 P. Reichard and L. Rutberg, Biochim. Biophys. Acta, 37 (1960) 554.

14 E. C. Moore and R. B. Hurlbert, Biochim. Biophys. Acta, 40 (I960) 37 I.

15 Z. Dische, in E. Chargaff and J. N. Davidson, the Nucleic Acids, Vol. I, Academic Press Inc., New York, I9.55, p. 286.

16 P. STumpF, J. Biol. Chem., I69 (1947) 367.

17 M. Friedkin and D. Roberts, J. Biol. Chem., 207 (1954) 257.

18 D. L. MacDonald and H. G. Fletcher, J. Am. Chem. Soc., 82 (1960) I832,

19 J. C. Garver and R. L. Epstein, Appl. Microbiol., 7 (I959) 3 Is.

20 C. G. Smith and M. J. Johnson, J. Bacteriol, 68 (I954) 346.

21 W. E. Pricer JR. and B. L. Horecker, J. Biol. Chem., 235 (1960) 1292.

22 E. Racker, Methods in Enzymology, I (1955) 384.

23 J. G. Buchanan, Nature, I68 (195I) IOgI.

24 L. WARREN, Nature, I 86 (1960) 237.

${ }_{25}$ G. T. Cori, S. P. Colowick And C. F. Cori, J. Biol, Chem., I24 (I938) 543.

26 V. A. NAJJAR, J. Biol. Chem., I75 (I948) 28I. 